\title{
HEGEL E O BUDISMO COMO CONSCIÊNCIA DE SI MESMO ASPECTOS DE UMA CRÍTICA
}

\author{
Deyve Redyson $^{1}$
}

\begin{abstract}
Resumo: Este trabalho tem como principal objetivo analisar a interpretação realizada por Hegel do budismo. Através das obras Lições sobre a Filosofia da História e Lições sobre Filosofia da Religião encontramos o caminho elaborado por Hegel para fundamentar sua tese sobre a filosofia da religião e em consequência a perspectiva que obteve das religiões orientais como o budismo. Percebe-se que o momento da filosofia da religião em Hegel é também um movimento de seu sistema da ciência em virtude das características que estão presentes desde sua Ciência da Lógica até as obras relativas à religião. Quando Hegel analisa o budismo utiliza referências de sua época que o levam a uma interpretação equivocada da filosofia budista, de suas práticas e ritos e desenvolve, dentro da história da filosofia, uma fundamentação ao oriente que a torna complexa e sem nenhuma possibilidade de legitimação dentro da estrutura de pensamento. O texto analisa os pontos positivos e negativos do pensamento de Hegel sobre o budismo.
\end{abstract}

Palavras-chave: Filosofia da religião, Orientalismo, Budismo, Ser-em-si.

Abstract: This work aims to analyze the interpretations of Hegel Buddhism. Through the works of Lectures on the Philosophy of History and Lectures Philosophy of Religion about the way we find elaborated by Hegel to substantiate his thesis on the philosophy of religion and consequently the prospect that got Eastern religions such as Buddhism. It is noticed that the moment of Hegel's philosophy of religion is also a movement of his system of science because of the features that are present from his Science of Logic to the works relating to religion. When Hegel examines Buddhism uses references of his day that lead to a misinterpretation of Buddhist philosophy, their rites and practices and develops within the history of philosophy, a statement of reasons to the east which makes it complex and without any possibility of legitimacy within the structure of thought. The text analyzes the strengths and weaknesses of Hegel's thought about Buddhism.

Keywords: Philosophy of Religion, Orientalism, Buddhism, Being-in-itself.

\footnotetext{
${ }^{1}$ Professor do Departamento de Ciências das Religiões e do Programa de Pós-graduação em Ciências das Religiões da UFPB. Doutor em Filosofia da Religião pela Universidade de Oslo - Noruega. E-mail: dredyson@gmail.com.
} 


\section{Introdução}

G. W. F Hegel (1770-1831) poderá ser considerado como um dos grandes interlocutores da filosofia da religião (Religionsphilosophie) que terá seu início dentro de uma perspectiva que envolveu tanto a teologia natural quanto a teologia revelada. Hegel também poderá ser compreendido como o filósofo que inaugurou, de alguma forma, a preeminência de ler filosoficamente outras religiões além do cristianismo. $\mathrm{O}$ contexto no qual o pensamento sistemático de Hegel rompe a leitura estritamente cristã da religiosidade pode por um lado, representar um avanço da filosofia ocidental em tentar interpretar o oriente, mas por outro efetivar uma imposição de ideias que representam uma unanimidade de pensamento estritamente ocidental.

Embora pensadores como Leibniz tenha dialogado com tradições orientais chinesas, entendemos que será em Hegel que algumas religiões orientais terão mais espaço. Obviamente a forma hegeliana de interpretar o mundo oriental legou também diversos problemas de natureza conceitual e em alguns momentos até preconceituosa do filósofo alemão com estas religiões que se desenvolveram no extremo oriente. Alguns trabalhos já foram escritos sobre a natureza das críticas de Hegel às religiões da Índia como se pode ver, por exemplo, nos trabalhos de MARTINS (1983), VIYAGAPPA (1980) e HULIN (1979) ou mesmo sua total exclusão enquanto elemento de importância em suas Lições como em CHAPELLE (1964).

Hegel, assim como sua época, representou um momento impar dentro da história do pensamento do que ficou conhecido como orientalismo europeu, livros e pesquisas sobre temas orientais chegaram a língua alemã, inglesa, italiana e francesa fornecendo assim material para que este orientalismo surgisse. A conhecida tradução de 50 das 108 Upanishads de Antequil Duperron acabou por contribuir e exerceu muita influência nas obras de Schopenhauer, dos irmãos Schlegel e do próprio Hegel, além de diversos outros pensadores. Neste artigo não pretendemos incluir nenhum elementos dentro da visão e interpretação hegeliana do oriente e sim analisar as impressões de Hegel para com o budismo, especialmente em duas de suas obras: As Lições sobre Filosofia da Religião (Vorlesungenüber der Philosophie der Religion) e Filosofia da História (Philosophieder Geschichte). Para isso compreendemos três formulações iniciais que nos permitiram tal interpretação: 1) Hegel insere sua Filosofia da Religião em seu sistema da ciência (System der Wissenschaft), mas a perspectiva oriental não é considerada; 2) Hegel dispunha de traduções razoavelmente mal elaboradas sobre temas

\begin{tabular}{|l|l|l|l|l|}
\hline Qevista Dialectus & Ano 2 & n. 4 & Janeiro-Junho 2014 & p. 63-77 \\
\hline
\end{tabular}


orientais e 3) Hegel ao interpretar determinadas passagens orientais não utiliza seu espírito (Geist) filosófico por considerar estas religiosidades (Religiöse)práticas espirituais e não filosofias. Embora estes argumentos se demonstrem críticos nossa perspectiva é avaliar o diálogo que Hegel teve, de forma interpretativa, com o budismo.

\section{Hegel e o Budismo nas Lições de Filosofia da História}

Um primeiro argumento que pode ser considerado de forma uníssona é que os temas que envolvem o oriente e mais especificamente o budismo surgem nas obras de Hegel apenas em suas lições, isto é, em suas principais obras como a Fenomenologia do Espírito, ou na Ciência da Lógica não encontramos uma predisposição de nosso autor a trabalhar com tais religiões, pois suas finalidades são outras. A primeira justificativa à esse argumento pode ser dada dentro do que podemos chamar de perspectiva sistêmica de Hegel, pois, não podemos esquecer que a finalidade do sistema não é a religião e sim a lógica. Dessa forma os primeiros elementos que envolvem budismo podem ser encontrados em suas Lições sobre Filosofia da História (Vorlesungen über die Philosophie der Geschichte). Estas Lições foram ministradas num longo período, compreendem desde 1805 até 1830, mas somente foram publicadas em 1837, seis anos após a morte de Hegel. Esta obra representa um estágio muito avançado do pensamento de Hegel, um estado onde ele já tinha amadurecido em seu máximo suas concepções sobre a história, isto é, o mundo e sua esfericidade, nunca abandonando seu esquema triádico que caracteriza seu pensamento: a lógica, a natureza e o espírito.

Após uma longa introdução à Filosofia da História, onde aborda os três elementos do princípio universal da história filosófica: história original, história refletida e história filosófica, Hegel em sua primeira parte detrata do mundo oriental, que em sua leitura contempla a China, a Índia, o budismo e a Pérsia. A segunda, terceira e quarta partes dizem respeito ao mundo grego, mundo romano e mundo germânico. Perceba-se que Hegel nos fala, inicialmente de três localizações e uma doutrina que é o budismo, que por sua natureza nasceu na Índia. Sua primeira constatação é a de que: "O mundo oriental tem como princípio mais próximo a substancialidade do fator moral" (HEGEL, 2008, p. 101). Hegel caminha em direção de demonstrar que o mundo oriental não gerou uma filosofia que possa ser entendida como filosofia para o ocidente, mesmo reconhecendo a sua substancialidade essa forma de pensamento, oriental, vincular-se-ia mais presentemente a história. A religião e a sociedade destes povos orientais estariam,

\begin{tabular}{|l|l|l|l|l|}
\hline Qevista Dialectus & Ano 2 & n. 4 & Janeiro-Junho 2014 & p. 63-77 \\
\hline
\end{tabular}




\section{HEGEL E O BUDISMO COMO CONSCIÊNCIA DE SI MESMO...}

Deyve Redyson

segundo Hegel, mais voltados a sua essência em si mesmos do que na efetivação de uma estruturação do pensar. Hegel aponta que a ideia de Deus não tinha alcançado ainda estes povos: "O que denominamos Deus ainda não foi concretizado no oriente, pois nosso Deus surge só na elevação para o sobrenatural e somente quando obedecemos, porque o que fazemos surge de nós mesmo" (Idem).

Após um capítulo sobre a China, em que não aponta aspectos religiosos e sim políticos, chegamos ao momento em que Hegel se depara com a Índia. Hegel não consegue separar os elementos políticos e religiosos, aspectos que denotam a vivacidade desde povo. Chega mesmo a destacar a beleza das mulheres indianas por terem pele e rosto ruborizados (Ibidem, p. 123), expressa questões geográficas e a todo o momento faz relação e comparações com a China e com as representações das castas e com os principais deuses da Trimurti (Brahma, Vishnu, Shiva). Além disso, Hegel relata com frequência as conclusões de um certo inglês que teria visitado a Índia e testemunhado diversos rituais e sacrifícios aos quais ele se apoia como fonte para estabelecer seus conceitos. Aparecem no seu texto referências ainda sobre os orientalistas Christian Rosen, Friedrich Schlegel, William Jones e Colebrooke ${ }^{2}$.

Hegel dedicará o terceiro capítulo ao budismo, e nele ficam expressas informações que nos permitem demonstrar o quanto nosso autor era desconhecedor do budismo e de suas tradições, pois segue o raciocínio que obteve das outras religiões orientais como o hinduísmo. No início do capitulo, Hegel situa seu leitor, público já bem conhecedor do cristianismo, o que é o budismo seguindo considerações a partir de alguma literatura que tinha a disposição. Percebe-se que Hegel conhece as origens do budismo e sua situação geográfica. Os elementos responsáveis pela equivocada interpretação de Hegel sobre o budismo começam na sua fonte de leitura e em seguida a partir de sua visualização do tema. A principal fonte utilizada por Hegel para os seus desenvolvimentos, em todo o seu capítulo sobre o budismo foi o artigo de Francis Buchanan OnthereligionandliteratureoftheBurmas publicado no volume 6 do AsiaticResearches que expõe a natureza do budismo em sua genealogia histórica, através das histórias do nascimento do BuddhaShakyamuni, passando pelos principais conceitos sobre o sofrimento e termina por entronizar que existem escolas budistas diferentes que desenvolvem estruturas monásticas, como o Tibete, por exemplo. O texto de Buchanan traz problemas, pois ele quer descrever o desenvolvimento histórico do

\footnotetext{
${ }^{2}$ Vale ressaltar que Hegel dispunha em sua biblioteca os títulos orientais mais em voga entre o século XVIII e XIX (Cf. em Fuentes de la filosofia de la religión de Hegel; In: HEGEL, 1987, p. 313-328.
}

\begin{tabular}{|l|l|l|l|l|}
\hline Qevista Dialectus & Ano 2 & n. 4 & Janeiro-Junho 2014 & p. 63-77 \\
\hline
\end{tabular}




\section{HEGEL E O BUDISMO COMO CONSCIÊNCIA DE SI MESMO...}

Deyve Redyson

budismo a partir de narrativas míticas do Buddha que se encontram nas conhecidas História Jatakas do cânone páli. Começando a ler o budismo por tais histórias somente evidenciará que a perspectiva búdica é mítica e que os desenvolvimentos seguintes como as quatro nobres verdades e o nobre caminho óctuplo, de alguma forma são mantidos por estas narrativas míticas. Hegel, naturalmente, faz uma cosmologia identificando aspectos míticos no budismo e, portanto entendendo esta doutrina como uma espécie de fantasia que se tornou devoção de forma semelhante ao que pensa do hinduísmo.

O texto de Buchanan levanta questões fulcrais para não compreender o budismo, além de começar por uma evidência mítica ele não permite que se compreenda a formação das escolas e tradições dentro do budismo, isto é, a impressão que se fica ao ler Buchanan é que, todas as tradições convergem numa grande harmonia e que elas são mutuamente e historicamente da mesma época. Hegel, em algumas passagens acaba por comprar o discurso de Buchanan e deprecia diversos conceitos do budismo, extraindo deles pré-conceitos com a doutrina dos renascimentos e da Lei do Karma. Somente em 1857, os problemas instáveis em Buchanan foram sanados de alguma forma por Koeppen na obra Die Religion des Buddha und ihre Entstehung que consegue imprimir uma visão um pouco mais clara do budismo. A obra de Koeppen fora lançada após da morte de Hegel e por esse motivo nosso autor não pôde fazer uso dela.

Podemos ver a influência de Buchanan sobre Hegel na seguinte passagem pontual:

O espírito da forma descrita possui o mesmo princípio básico da intuição hindu, porém ele é mais concentrado em si mesmo, sua religião é mais simples e sua situação política mais calma e comedida. Povos e países altamente diferenciados reúnem-se aqui: Ceilão, Índia oriental com o império da Birmânia, Sião e Anam, ao norte do Tibete; depois vem o planalto chinês com as suas diversas tribos de mongóis e tártaros... A religião desses povos é o budismo... A religião mais difundida em nosso planeta terra (HEGEL, 2008, p. 145).

Aqui se pode perceber que a leitura de Hegel tem por base a doutrina hindu e suas experiências fantásticas, pois Hegel acredita que o mesmo princípio básico que rege algumas categorias do hinduísmo rege também e da mesma forma o budismo. $\mathrm{O}$ único elemento do qual Hegel se utiliza é o de que este princípio básico é mais concentrado em si mesmo. Com isso podemos ver que o budismo que Hegel se refere é um tipo de religião egoíca. A perspectiva hindu é bastante diferente da budista, são configurações amplamente diferentes. No hinduísmo, e Hegel conhece isso, as práticas divinatórias partem de preceitos variados que se referem cada um a uma espécie e tipo

\begin{tabular}{|l|l|l|l|l|}
\hline Qevista Dialectus & Ano 2 & n. 4 & Janeiro-Junho 2014 & p. 63-77 \\
\hline
\end{tabular}




\section{HEGEL E O BUDISMO COMO CONSCIÊNCIA DE SI MESMO...}

Deyve Redyson

de entidade ou divindade, por isso os sacrifícios são realizados de diversas formas e se tem diversas invocações. Neste sentido a religião budista torna-se mais calma e comedida como acentua Hegel. O detalhe que falta a esta interpretação é movida pelo desconhecimento das várias tradições do budismo após o terceiro concílio budista, que criara as primeiras dezoito escolas e estas passaram a representar a tradição Hinayana, de perseguir individualmente a iluminação búdica. A leitura de dentro da tradição Mahayana já nos permitiria compreender um segundo giro da roda do Dharma que evidencia a iluminação pessoal e dos outros. A informação da difusão do budismo no planeta terra, utilizada por Hegel, é de Buchanan e foi a expressão mais usual na época até a chegada do livro de Koeppen.

Hegel, ainda nas Lições sobre a Filosofia da História identifica o termo Fo como a representação do Buda na China e nos dá traços de sua expansão. Na tentativa de expressar sua doutrina, Hegel insere o budismo entre as religiões da interioridade e demonstra sua não substancialidade:

Nessa religião, que na verdade deve ser caracterizada como a religião da interioridade, a elevação da falta de espiritualidade para a subjetividade acontece de duplo modo, sendo um do tipo negativo e o outro do tipo afirmativo (Ibidem, p. 145-146).

Para Hegel, o budismo prega uma interioridade contemplativa sem espiritualidade e na relação de sua subjetividade transporta-se para uma efetiva intersubjetividade. O que Hegel quer é demonstrar como o cristianismo é superior a esta prática não espiritual:

A elevação negativa é a concentração do espírito ao infinito, que precisa ocorrer, primeiramente, em determinações religiosas. Ela reside no dogma fundamental de que o nada é o princípio de todas as coisas, de que tudo surge do nada e para lá retorna... Tudo é somente uma alteração de forma (Ibidem, p. 146).

O grande problema de Hegel se encontra no seu conceito de religião. A religião é tema que atravessa toda a sua obra, ou seja, seu sistema da ciência (System der Wissenschaft). A religião ou as figuras emblemáticas do cristianismo ocupam grande parte de seu percurso filosófico e nos lançam na empreitada de verificar onde a filosofia da religião hegeliana quer chegar e quer ser, pois ela faz parte do todo em seu sistema. Esta relação de intersubjetividade concerne o budismo como uma religião não espiritual e o conceito de religião de Hegel é prático e sistêmico, o espírito tem que reconhecer-se como espírito.

Ainda sob as pegadas de Buchanan, Hegel descreve que o budismo praticado no Ceilão tem pretensões únicas e que estes aspectos estão muito próximos de uma certa

\begin{tabular}{|l|l|l|l|l|}
\hline Qevista Dialectus & Ano 2 & n. 4 & Janeiro-Junho 2014 & p. 63-77 \\
\hline
\end{tabular}


salvação: "No Ceilão e no império Birmanês, onde essa fé no budismo tem raízes, domina a crença de que o homem poderia obter, pela meditação, a sua independência em relação à doença, à velhice e à morte" (Idem). A descrição é Theravada, o budismo que mais se disseminou pelo Ceilão e pela Birmânia, que baseando-se no Dhammacakkappavattana Sutta (Colocando a roda do Dhamma em movimento) do cânone páli efetivam que existe o sofrimento $(d u k k h a)$, que se deve descobrir as origens do sofrimento (dukkhamudaya) em seguida conhecer que o sofrimento pode ser cessado (dukkhaniroda) e por fim entender o caminho que conduz à cessação do sofrimento (dukkhanirodagaminipatipada). Da forma que Hegel descreveu nos parece que durante o processo de meditação se chega a ultrapassar doença, envelhecimento e morte simplesmente, quando o processo não visa independência destes três estágios e sim a compreensão destes três estados como impermanente. Continua Hegel:

Se esse é o modo negativo da elevação do espírito, de sua exterioridade para si mesmo, assim essa religião desenvolve-se, também, para a consciência de uma afirmação. O absoluto é o espírito. Porém, a compreensão dele depende essencialmente da forma determinada na qual ele é concebido (Idem).

Dentro da visão filosófica de uma das mais conhecidas escolas budistas, a Yogacara, o que há é apenas mente e os dados imediatos da consciência efetivam o que há em sua exterioridade e não em sua realidade fenomênica. Dessa forma não é tão correto entender que no budismo o absoluto é o espírito, pois primeiro teríamos que definir essa categoria absoluto para que ele seja no espírito.

Se em uma página Hegel inicia um diálogo filosófico na página seguinte ele volta para a história e insere-se no Tibete, afirmando que os povos que habitam naquelas montanhas veneram o lama e que esta veneração envolve uma sociedade patriarcal. Segundo Hegel:

De fato, existem três lamas: o mais conhecido é o dalai-lama, que tem sua
sede em Lhassa, no império do Tibete; o outro é o tichu-lama, que tem o
título pan-chen-rin-po-che, e reside em Tichu-Lombu; o terceiro está no sul
da Sibéria. Os dois primeiros lamas são os seres supremos de duas diferentes
seitas, cujos sacerdotes usam, em uma delas, um capuz amarelo, e na outra,
um vermelho. Os de capuz amarelo, cujo ser supremo é o dalai-lama, com
quem o imperador da China mantém boas relações, introduziram o celibato
entre os sacerdotes, enquanto os de capuz vermelho permitem o casamento
dos mesmos. Os ingleses travaram conhecimento especialmente com o tichu-
lama, e nos forneceram dados sobre eles" (Ibidem, p. 147).

Esta passagem é repetida por Hegel em suas Lições sobre Filosofia da Religião. E todas as referências que Hegel possuía sobre o budismo no Tibete estavam no Allgemeine Historie der Reise zu Wesser und zu Lande, volume 6 e 7, publicado em Leipzig em 1750.

\begin{tabular}{|l|l|l|l|l|}
\hline Qexista Dialectus & Ano 2 & n. 4 & Janeiro-Junho 2014 & p. 63-77 \\
\hline
\end{tabular}


A passagem de Hegel sobre o budismo tibetano deve ser melhor entendida. O primeiro problema é na zona geográfica do Tibete e de sua suposta divisão em três lamas supremos. Quando Hegel emprega a palavra seita, ele está citando o termo dos Allgemeine Historie que fora uma tentativa de representar as principais linhagens budistas no Tibete. Os chapéus amarelos são os praticantes da linhagem Gelugpa a qual pertence até hoje o dalai-lama e os chapéus vermelhos são praticantes da linhagem Nyingma, conhecidos como os mais antigos. Outras duas grandes linhagens já existiam nesta época, a Kagyue a Sakya, além do budismo Bön que recolhia tradições religiosas antigas do Tibete. Hegel se equivoca quando pressupõe que Lhasa é o Tibete e que o outro supremo lama, o panchen lama, está em outra localidade que não o Tibete, e em suas Lições confundirá a atividade do dalai lama, como ministro político com a do panchen lama. A tendência do Allgemeine Historie partia do entendimento de que o budismo que se propagou no Tibete em alguns lugares era de fato budismo, por cultuar o Buddha e em outras regiões dominava o lamaísmo, pois se cultuava o lama e ouras entidades. Powers (2007, p. 197) nos informa que determinadas regiões do Tibete tinha a figura do lama como uma divindade e que em outras partes dos himalaias o lama simplesmente representava uma atitude política sob uma inspiração. A informação que Hegel obteve estava correta, lamas da Gelugpa não se casam e os da Nyingma podem contrair matrimônio.

Outra informação importante para compreender o que os textos da época de Hegel afirmavam sobre o Tibete, foi o início do século XVI quando houve uma grande aliança entre o Tibete e o rei da Mongólia, estes protegiam o território do Tibete e os monges se tornavam guias espirituais dos mongóis e não dos chineses. No ano de 1578 Sonam Gyatso, abade do mosteiro de Drepung é convidado pelo chefe mongol, Altan Khan, a visitar seu reino. A extrema inteligência desta abadia impressionou de tal forma o líder mongol que este o chamou de $T a L e$, que pode ser traduzido por oceano de sabedoria, ao chegar ao Tibete esta expressão se tornou Dalai Lama. Dessa forma, Sonam Gyatso foi conhecido como o III Dalai Lama, terceiro porque o próprio Sonam teria aprendido o que sabia com dois mestres, que retroativamente foram chamados de I e II Dalai Lama: Gendrun Drubpa (1391-1474) e Gentum Gyatso (1475-1542). O IV Dalai Lama foi Yonten Gyatso (1589-1616) e deu continuidade ao acordo com os mongóis e os Gelugpa. Ngawang Losang Gyatso (1617-1682) foi reconhecido como o V Dalai Lama, politicamente unificou o território e instaurou o Estado do Tibete que era formado por monges e leigos. No ano de 1645 tem início a construção do palácio Potala

\begin{tabular}{|l|l|l|l|l|}
\hline Qevista Dialectus & Ano 2 & n. 4 & Janeiro-Junho 2014 & p. 63-77 \\
\hline
\end{tabular}


que será o palácio dos dalai lamas, a construção só terminará em 1695. O primeiro Dalai Lama que efetivamente terá uma participação política no estado do Tibete foi o XIII, Thubten Gyatso (1876-1933), que exerceu grande papel político frente aos mongóis para delimitar fronteiras e diante da crescente ameaça de invasão do Tibete, o XIII Dalai Lama, fortalece o exercito tibetano. A primeira, e fraca, invasão ao Tibete ocorre no ano de 1910, facilmente os tibetanos expulsam os invasores (cf. NINA, 2006; POWERS, 2007).

\section{Hegel e o Budismo nas Lições sobre Filosofia da Religião}

Em sua obra Vorlesungenüber die Philosophie der Religion (As Lições sobre a Filosofia da Religião) encontramos, pela primeira vez escrito uma sistematização das religiões e de suas finalidades. As Lições sobre religião proferidas por Hegel foram lecionadas em anos diferentes, o que torna sua sistematização complicada, pois os seus quatro principais manuscritos partem de uma construção em evolução. As lições foram dadas em 1821 e repetidas em 1824, 1827 e finalmente em 1831, que nos levam a compreender inicialmente o conceito de religião e em seguida breves analises sobre as religiões que teve conhecimento. As Lições sobre Filosofia da Religião vão se dividir da seguinte forma: O Conceito de Religião (Der Begriff der Religion) e estende-se em: A Religião Determinada (Der Bestimmte Religion) e a Religião consumada ou absoluta (Der Absolute Religion). A religião determinada consiste na religião natural, isto é, a religião primitiva e oriental, depois Hegel nos fala de uma religião da individualidade espiritual onde se encontra, por exemplo, o judaísmo e a religião grega, a religião romana ou imperial e a unidade entre religiões e doutrinas.

A filosofia da religião é também, para Hegel, uma exposição sistemática de pensamento, onde não há um dualismo, isto é, não há duas razões ou dois espíritos, não existem uma razão divina e uma razão humana que operam cada uma por seu lado, mas sim uma única razão. A razão do homem é o que há de divino no homem e a ideia de espírito de Deus não é um espírito que se encontra lá no céu distante dos homens, como um ser extramundano. A intenção fundamental de Hegel consiste em situar dialeticamente identidade e diferença.

$\mathrm{Na}$ introdução aos cursos de filosofia da religião, Hegel analisa a natureza da religião em geral e suas relações com a filosofia para assim chegar a uma filosofia da religião através de seu próprio desenvolvimento. Será nas lições sobre sua filosofia da

\begin{tabular}{|l|l|l|l|l|}
\hline Qevista Dialectus & Ano 2 & n. 4 & Janeiro-Junho 2014 & p. 63-77 \\
\hline
\end{tabular}




\section{HEGEL E O BUDISMO COMO CONSCIÊNCIA DE SI MESMO...}

Deyve Redyson

religião onde encontraremos as maiores considerações de Hegel sobre o budismo. A primeira constatação hegeliana é que o budismo é uma religião natural, assim como todas as outras religiões orientais. Esta nomenclatura é por si só bastante considerável, pois, por religiões naturais ou da natureza, Hegel estaria vinculando a noção de crença à noção de natural o que poderia suspender, dentro de uma cosmologia, as religiões que não teriam livro sagrado, profecia ou única divindade. Podemos assim esquematizar a tábua de religiões para Hegel a partir das Lições sobre Filosofia da Religião:

\begin{tabular}{|ll|}
\hline A. & Religiões da Natureza \\
\hline I. & Religião imediata, natural: magia \\
\hline II. & Religiões da consciência dividida em si mesma (religiões da substância) \\
a) Religião da medida (China) \\
b) Religião da fantasia (brahmanismo) \\
c) Religião do ser em si (budismo) \\
\hline III. Religiões da substância livre \\
a) Religião do bem e da luz (Persa) \\
b) Religião do sofrimento (Síria) \\
c) Religião do mistério (Egito) \\
\hline B. Religiões da Individualidade espiritual \\
\hline a) Religião do sublime (judaísmo) \\
b) Religião da beleza (grega) \\
c) Religião da finalidade (romana) \\
\hline C. Religião da finalidade absoluta \\
a) Cristianismo
\end{tabular}

Partindo desta tábua da concepção de religiões de Hegel, percebemos que o seu autor divide em três grupos as religiões A, B e C. As Religiões da natureza se dividem em outras três formações religiosas que compreendem as religiões do oriente (próximo e extremo). A segunda classificação de religiões também se divide em outras três, a saber, as religiões que de alguma forma se encontram com o cristianismo: o judaísmo, as religiões gregas e romanas e por fim a terceira classificação remonta-se unicamente a religião cristã entendida como Religião da finalidade absoluta.

\begin{tabular}{|l|l|l|l|l|}
\hline Qevista Dialectus & Ano 2 & n. 4 & Janeiro-Junho 2014 & p. 63-77 \\
\hline
\end{tabular}


Tanto nas Lições sobre Filosofia da Religião como na Filosofia da História ou na História da Filosofia poderemos encontrar um ar preconceituoso de Hegel em relação à possibilidade da existência de filosofia no oriente, para ele, claramente se define o pensar filosófico como característica exclusiva do ocidente. Ao oriente resta apenas a característica da espiritualidade como se pode ver em Buda, Confúcio ou Lao Tsé.

Para mapearmos a interpretação dos conceitos orientais na filosofia de Hegel teremos que mergulhar dentro de sua lógica e de sua forma de escrita e de conclusões. Efetivamente encontraremos as conclusões de Hegel sobre o pensamento oriental em suas lições onde evoca o hinduísmo, o budismo e as tradições chinesas.

Sobre o hinduísmo, Hegel tem uma forte impressão, pois os julga como donos de uma religião da fantasia, isto é, mitificada por seus sacrifícios e rituais que exaltam principalmente as divindades escondidas nas terras. Hegel entende por hinduísmo uma religião onde não há o bem e que a noção de consciência está atrelada ao ser que não é (cf. HEGEL, 1984, p. 207s), são naturais porque estão ligadas a espíritos das florestas e das montanhas. Hegel ignora a existência de sistemas de pensamento heterodoxos ou ortodoxos, o materialismo, enfoca apenas o necessarísmo mítico e ritualístico das religiões brahmanicas. Ainda podem ser encontrados diversos outros problemas nas conceituações de Hegel sobre o budismo, o confucionismo ou mesmo o taoísmo.

É visível dentro desta escala desenvolvida por Hegel uma grande predileção por religiões como o cristianismo, por exemplo, e uma total depreciação às religiões orientais, entendidas como religiões da substância e não do absoluto, como prefere Hegel em seu sistema filosófico de ideias. Em muitos dos momentos de suas lições, Hegel aponta para o avanço que as religiões tiveram em direção ao cristianismo, essa evolução é percebida através de seu surgimento histórico, político e de sua propagação pelo mundo, Hegel aponta, por exemplo, que o islamismo é uma religião inferior ao cristianismo por não trazer uma ideia clara de sentido e de crença, e aponta também, que partindo de sua conceituação e de sua sequência cronológica não se saiu tão claramente como obteve a evolução filosófica.

Os fatos históricos parecem ser muito importantes para Hegel quando fala do budismo, pois na Filosofia da Religião ele repete algumas informações presentes nas lições sobre Filosofia da História, como a da representação de Fo como o Buda na China. Nos diz Hegel:

\begin{tabular}{|l|l|l|l|l|}
\hline Qevista Dialectus & Ano 2 & n. 4 & Janeiro-Junho 2014 & p. 63-77 \\
\hline
\end{tabular}




\begin{abstract}
"Para nos referimos ao histórico, ao existente como fora determinado anteriormente, a religião de Fo na China é a religião dos chineses, mongóis e tibetanos, também dos birmanos e dos cingaleses, com a diferença de que estes denominam o Buda de Fo dos chineses; mas ambas as coisas são equivalentes e são a religião que conhecemos sob a forma de lamaísmo (HEGEL, 1985, p. 189).
\end{abstract}

Segundo Tucci (1973), o Lamaismo é a forma de institucionalismo que surgiu no Tibete para legitimar o poder dos lamas e suas convenções. Hegel entende o lamaísmo como uma religião de características budistas onde na verdade o budismo tibetano nada mais é do que uma forma de budismo que se configurou no Tibete.

Mais adiante encontramos mais detalhes sobre o que Hegel chama de religião lamaísta: "A leve diferença entre a religião de Fo e do lamaísmo é somente artificial. Na religião do Lama a figura e o aspecto da realidade é esta autoconsciência, um homem efetivo e vivo, mas existem vários desses lamas supremos" (HEGEL, 1985, p. 189). Aqui Hegel comete um erro, pois sua leitura está baseada em Die WichtigstenReisede Wilhelm Harnisch que apresenta o lamaísmo como uma religião independente do budismo. Harnisch apenas afirma na página 355 de seu trabalho que tanto o lamaísmo como o budismo são muito parecidos. O detalhe é que o lamaísmo é uma criação ocidental e tal expressão não existe, pois no Tibete o budismo tem características próprias, mas estas características próprias não fazem, do budismo praticado no Tibete, uma outra religião. Nas lições sobre Filosofia da História Hegel já afirmava isso, outra vez baseado nas informações de Harnisch: "No Tibete e entre os mongóis essa religião manteve a matriz do lamaísmo" (HEGEL, 2008, p. 145).

Dessa forma a crença lamaíca foi entendida no ocidente, inicialmente, como uma crença em que a figura do Lama estabelecia-se de forma superior ao Buda e que seus ensinamentos, de alguma forma, substituíam os do Buda. A exemplo disso, se pode dizer da crença dos tibetanos em reconhecer uma criança como o renascimento de um grande mestre, dessa forma a criança será criada como um mestre e aprenderá os desígnios ao qual foi preparado em outras vidas.

As informações que Hegel obteve sobre o budismo tibetano soam profundamente equivocadas e ao mesmo tempo provocaram uma depreciação dessa forma de budismo, tanto pelo equivoco da leitura como da interpretação proposital de Hegel. Hulin e Droit acreditam que esta visão de Hegel foi possível a partir dos convencionamentos ocidentais que entendiam o budismo como uma religião soteriológica, isto é, na efetivação de que o Buda seria um salvador igual a Jesus Cristo e que ensinara uma doutrina em que seus fieis (praticantes) deveria honrá-lo e nele

\begin{tabular}{|l|l|l|l|l|}
\hline Qevista Dialectus & Ano 2 & n. 4 & Janeiro-Junho 2014 & p. 63-77 \\
\hline
\end{tabular}


confiarem (cf. HULIN, 1979, p. 127). Já mensurando esta alternativa, a ideia de que o budismo seria uma forma religiosa onde o nada ou a nadificação teria sua primazia, onde doutrinariamente o que o Buddha ensinara fosse uma teoria onde nada existe pelo fato de não haver um paraíso ou não desenvolver a ideia de um Deus, tornou-se consonante com uma religião niilista (cf. DROIT, 2003, p. 60-61) teve um impacto muito grande em toda a Europa, isto é, o budismo fora entendido como uma religião niilista. Estas perspectivas apontadas por Droit e depois por D'Amato e Moore foram uma realidade para os filósofos do século XVIII, pois ao lerem a literatura da época sobre budismo não poderia se ter outra conclusão a não ser a de que o budismo se efetivava como uma doutrina niilista que pregava a crença em nada. Hegel numa rápida citação em sua Enciclopédia das Ciências Filosóficas deixa clara esta realidade em sua época, quando falando de pura abstração, portanto o absolutamente-negativo no entendimento de que o absoluto também é o nada afirma:

Ou ainda, que Deus é somente o ser supremo, e nada mais além disso; pois enquanto tal ele é expresso como exatamente a mesma negatividade: o nada que os budistas fazem o princípio de tudo, com seu fim último derradeiro e meta de tudo, é a mesma abstração (HEGEL, 1995, p. 178)

Para o nada a negatividade já é suficiente, pois, inicialmente o ser e o nada são diferentes, mas em si, mas que ainda não está posta (cf. D’AMATO; MOORE, 2011, p. 24).

No prajnaparamitahdraya sutra (Sutra do Coração) uma das passagens mais pontuais de toda a realidade dos fenômenos do budismo mahayana se fundamenta na expressão: vazio é forma, forma é vazio, isto é, a natureza dos fenômenos está contemplada em uma determinada vazies dos elementos e das coisas que estes elementos trazem, isto é, não será necessário entender o que é o vazio ou o que é forma, dentro do prajnaparamita, e sim perceber que todos os fenômenos são vazio por sua natureza, isto é, são vacuidade.

Ainda sobre o budismo continua Hegel: "Sua essência consiste em existir sem atividade ou vontade, pois o nada é idêntico em si mesmo numa forma abstrata... No Ceilão e no império birmanês, onde essa fé no budismo tem raízes, domina a crença de que o homem poderia obter, pela meditação, a sua independência em relação à doença, à velhice e à morte" (HEGEL, 2008, p. 146). Percebe-se a falta de informação sobre a teoria interdependente dos mundos e sobre os agregados da existência. Hegel fala filosoficamente na abstração e no nada, tema caro a sua filosofia, como o sentido do ocidente em clarear a intuição mesma e sua efetividade do real, para Hegel, ainda,

\begin{tabular}{|l|l|l|l|l|}
\hline Qevista Dialectus & Ano 2 & n. 4 & Janeiro-Junho 2014 & p. 63-77 \\
\hline
\end{tabular}




\section{HEGEL E O BUDISMO COMO CONSCIÊNCIA DE SI MESMO...}

Deyve Redyson

podemos perceber o abstrato através de uma subjetividade de si e do outro, o outro está em si como consciência do mesmo, eis o fundamento de sua Fenomenologia do Espírito e sua caracterização idealista. Ainda na mesma esteira Hegel descreve a situação do Lama tibetano:

\footnotetext{
Esses lamas levam uma vida totalmente isolada e possuem uma formação mais feminina do que masculina. Tirado desde cedo dos braços dos pais, o lama, de modo geral, é uma criança bela e bem formada. Ele é criado em total silêncio e solidão, num tipo de prisão; bem alimentado... (Ibidem, p. 148).
}

Hegel com esta afirmação acaba por deturpar o estilo austero ao qual é submetido a escolha do Lama e descarta a possibilidade de esta criança se a representação de um mestre, que se origina no ascetismo e suas práticas mortificadoras.

De fato a compreensão do processo lamaíco é coisa de quem, na verdade, pratica o budismo tibetano, pois a crença de que um mestre realizado descreverá e anunciará onde irá renascer nunca poderia ser acreditado na época de Hegel na Alemanha, o recolhimento da criança, o ensino, as práticas, os estudos e principalmente a vivência religiosa não seria elementos para aquela era entender.

Ao voltarmos a tábua das religiões definida por Hegel em suas Lições sobre Filosofia da Religião, encontramos a conceituação hegeliana ao budismo. Primeiro entende Hegel que esta religião pertence as religiões da natureza e em seguida podem ser configuradas como Religiões da consciência dividida em si mesma, isto é, religiões da substância. Ao pensar que o budismo é uma religião da consciência em si mesmo podemos entender que, para Hegel, no budismo existe uma ideia/noção de consciência que se direciona para a autocompreensão de si mesmo. Esta descrição de alguma forma se parece com o budismo Theravada, onde a ideia de chegar a iluminação pertence ao reino da individualidade espiritual. Ao entendê-la como religião da substância, que provavelmente retorna a si mesmo, estaria Hegel interpretando o budismo como uma forma de entender a mente e idealizar um caminho.

As expressões de Hegel não estão tão certas e nem tão erradas, pois no pensamento filosófico budista podemos encontrar uma enorme quantidade de esfericidades muito parecidas, como em Nagarjuna, por exemplo, que defende a ideia de que nunca em lugar nenhum surgiram entidades ou que elas em algum lugar ou de alguma forma existem. Da mesma forma o idealismo budista da escola Yogacara se aproxima desta realidade anunciada por Hegel quando, Vasubandhu, seu principal interlocutor, anuncia as estâncias para compreender a natureza a partir de dados da consciência em si mesmos.

\begin{tabular}{|l|l|l|l|l|}
\hline Qevista Dialectus & Ano 2 & n. 4 & Janeiro-Junho 2014 & p. 63-77 \\
\hline
\end{tabular}


Nossa conclusão final pode estar baseada na configuração de que Hegel, em sua leitura sistemática do budismo a partir das fontes que tinha a sua disposição na época é interinamente formada em bases extremamente complicadas de interpretação do pensamento budista e principalmente do budismo tibetano as entendo como religião do ser em si, niilista e que ao mesmo tempo se formos analisar demoradamente o conteúdo filosófico do sistema de Hegel e as teses formuladas por algumas escolas filosóficas budistas encontraremos inúmeras zonas de convergência e de complementaridade, o que deixaremos para outra oportunidade. Assim podemos concluir ao dizer que a leitura de Hegel do budismo foi equivocada por não ter fontes suficientes para entendê-la e ao mesmo tempo nos perguntamos se, houvessem fontes qualificadas sobre o budismo na época de Hegel, ele as teria interpretado corretamente? Ou esta interpretação correta poderia desconfigurar seu sistema quando tentasse inserir a religião nele? Também é fato que determinadas conjecturas do sistema hegeliano, de alguma forma, se aproxima das convenções budistas da época.

\section{Referências Bibliográficas}

CHAPELLE, Albert. Hegel et la Religion - 4 vols. Paris. Éditions Universitaires, 1964.

D'AMATO, Mario; MOORE, Robert T. The Specter of Nihilism: On Hegel on Buddhism. In: Student-Faculty Collaborative Research, 2011. Disponível em: http://scholarship.rollins.edu/cgi/viewcontent.cgi?article=1028\&context=stud_fac.

Acesso em 01 de maio de 2014.

DROIT, Roger-Pol. The Cult of Nothingness. The Philosophers and Buddha. Chapell Hill: The University of North Carolina Press, 2003.

HEGEL, G. W. F. Lecciones sobre filosofia de la religión - 3 vols. Trad. Ricardo Ferrara. Madrid: Alianza, 1984/1985/1987.

Filosofia da História. Brasília: Editora da UNB, 2008.

Enciclopédia das Ciências Filosóficas em Compêndio: A Ciência da Lógica. Trad. Paulo Menezes. São Paulo: Loyola, 1995.

HULIN, Michel. Hegel etL'Orient. Paris: J. Vrin, 1979.

MARTINS, Roberto de A. A Crítica de Hegel à filosofia da Índia. In: Textos Seaf, n. 5, p. 58-116, 1983.

VIYAGAPPA, Ignatius. G. W. F. Hegel's concept of Indian Philosophy. Roma: Gregoriam University Press, 1980.

\begin{tabular}{|l|l|l|l|l|}
\hline Qexista Dialectus & Ano 2 & n. 4 & Janeiro-Junho 2014 & p. 63-77 \\
\hline
\end{tabular}

